
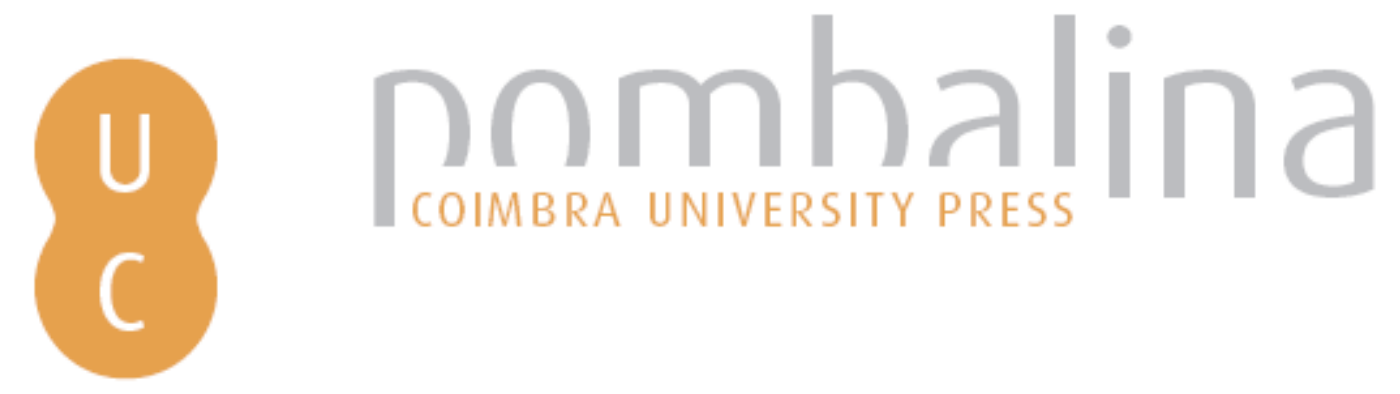

\title{
The FELS method of skeletal maturity
}

$\begin{array}{ll}\text { Autor(es): } & \text { Chumlea, William Cameron; Nahhas, Ramzi W.; Sherwood, Richard J.; } \\ \text { Duren, Dana L. }\end{array}$

Publicado por: Imprensa da Universidade de Coimbra

URL

persistente: URI:http://hdl.handle.net/10316.2/38543

DOI: $\quad$ DOI:http://dx.doi.org/10.14195/978-989-26-0773-3_1

Accessed : $\quad$ 26-Apr-2023 16:13:54

A navegação consulta e descarregamento dos títulos inseridos nas Bibliotecas Digitais UC Digitalis, UC Pombalina e UC Impactum, pressupõem a aceitação plena e sem reservas dos Termos e Condições de Uso destas Bibliotecas Digitais, disponíveis em https://digitalis.uc.pt/pt-pt/termos.

Conforme exposto nos referidos Termos e Condições de Uso, o descarregamento de títulos de acesso restrito requer uma licença válida de autorização devendo o utilizador aceder ao(s) documento(s) a partir de um endereço de IP da instituição detentora da supramencionada licença.

Ao utilizador é apenas permitido o descarregamento para uso pessoal, pelo que o emprego do(s) título(s) descarregado(s) para outro fim, designadamente comercial, carece de autorização do respetivo autor ou editor da obra.

Na medida em que todas as obras da UC Digitalis se encontram protegidas pelo Código do Direito de Autor e Direitos Conexos e demais legislação aplicável, toda a cópia, parcial ou total, deste documento, nos casos em que é legalmente admitida, deverá conter ou fazer-se acompanhar por este aviso.

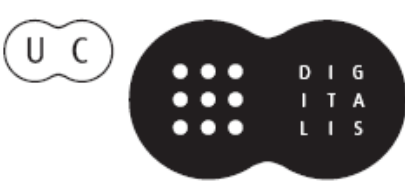




\section{GROWTH AND \\ MATURATION \\ IN HUMAN BIOLOGY \\ AND SPORTS}

FESTSCHRIFT HONORING ROBERT M. MALINA

BY FELLOWS AND COLLEAGUES

PETER TODD KATZMARZYK MANUEL J COELHO E SILVA

EDITORS 


\title{
THE FELS METHOD OF SKELETAL MATURITY
}

\author{
William Cameron Chumlea \\ Ramzi W. Nahhas \\ Richard J. Sherwood \\ Dana L. Duren
}

\section{INTRODUCTION}

Skeletal maturation, quantified as skeletal age, is the level of maturity expressed in years and months assigned to a bone or skeletal area irrespective of a child's chronological age (Roche et al., 1988). Skeletal age helps to account for maturational variance among children in clinical and epidemiological studies of growth, body composition, physical status and performance (Beunen et al., 1992; Malina et al., 1999; Claessens et al., 2006). The assessment of skeletal maturation is based upon the appearance, recognition and grading of maturity indicators. These are three dimensional features of a bone that appear twodimensionally on a radiograph. For example, an indicator can be the initial ossification of a bone or an epiphysis, the shape of a bone, a radio-opaque line or zone that represents the edge of a bone or increased ossification in the metaphysis and/or epiphysis with fusion. A maturity indicator must occur during the maturation of every child in order to be useful in determining skeletal age (Pyle \& Hoerr, 1969), and its progression of radiographic changes must appear in a regular sequential order as the bone matures to adult status (Roche, 1980). Skeletal age reflects the combined skeletal mechanisms occurring at different stages of growth and development based on the assumption of a universal progression of changes in the ossification, shape, joint formation, and epiphyseal fusion of bone(s) in the selected area of the skeleton in normal healthy children. During early childhood, skeletal age is primarily a measure of ossification onset; in mid-childhood it is a measure of changes in bone shape, individually and with respect to joint formation; and near the end of growth it measures the rate of epiphyseal fusion. Skeletal maturity is a system-wide phenomenon, but the assessment of skeletal maturation is typically done via hand-wrist radiographs. The hand-wrist is the most accepted site for skeletal maturity assessment due to its easy accessibility, the large number of bones in a very small area exposed to a small amount of radiation, and its history of numerous assessment methods (Roche, 1980; Cox, 1997).

\section{THE FELS METHOD}

The FELS method for assessing skeletal maturity independently grades sex- and agespecific maturity indicators for the twenty bones in the hand-wrist, the distal radius and ulna, the carpals and the first, third and fifth metacarpals and their corresponding phalanges. It was developed using 13,823 serial radiographs of the left hand-wrist from 355 boys and 322 girls in the Fels Longitudinal Study that were taken between 1932 and 
1977 (Chumlea, et al., 1989; Roche et al., 1988, 1992). Five criteria were used to select the maturity indicators: 1) discrimination, the ability of an indicator to distinguish between children at the same chronological age, 2) universality, the grades for an indicator occur during the maturation of each child, 3) high reliability, with both inter- and intra-observer differences in the prevalence of grades of an indicator of $8 \%$ or less, 4) validity, the prevalence of grades change systematically with age until the most mature grade for an indicator is universal, and 5) completeness, the extent an indicator clarifies and restricts the age ranges at which the final indicator grades are applicable. The FELS method provides a detailed description of indicators and the morphological differences between grades and presents radiographic pictures for the indicator grades of the bones to be scored. Some examples are the ossification and shape of the triquetral, the development of the hook of the hamate, the appearance of the styloid process of the radius, and epiphyseal fusion.

There are ninety-eight maturity indicators in the FELS method, but only subsets of indicators are used for assessment at any given chronological age. The non-selected indicators are those that do not vary between children at that selected age, and thus do not provide any maturational information. The number of indicators assessed ranges from a minimum of 21 for boys and 9 for girls at age 18 years (when adult status has occurred) to a maximum of 61 for boys and 64 for girls at 10 years of age which is a time of rapid skeletal maturation involving a number of ossification and epiphyseal changes. The assessed indicator grades are entered into a computer where the FELS software (Roche et al., 1988), a maximum likelihood based analysis of the maturity indicators, calculates a skeletal age and standard error. The FELS Method is the only skeletal age assessment method that provides a standard error or confidence limit for the calculated skeletal age. The median standard error for the FELS method is about 0.3 years from chronological age 6 months to 14 years in both boys and girls, and then increases to about 0.6 years in boys and 0.5 years in girls by age 18 years.

\section{Statistical Basis of the FELS Method}

The FELS Method utilizes a maximum likelihood technique to estimate a child's skeletal age using three classes of skeletal maturity indicators: binary indicators such as ossification, multiple grade indicators such as fusion and continuous indicators such as the ratio of epiphyseal to metaphyseal widths. The probabilistic behavior as a function of chronological age is modeled for each of these types of indicators. For example, the prevalence of children in the calibration sample who are immature for a given binary indicator is modeled as a logistic function of age, allowing estimation of the probability of maturity for that indicator at any given age. The calibration sample was used to estimate the parameters of each indicator's probability distribution as a function of age. The FELS method skeletal age for a child is the chronological age at which that child's indicator values are most likely in the calibration sample; that is, in the calibration sample, the chronological age at which one is most likely to find a child with similar values of the assessed indicators. This age, along with its standard error, is estimated using maximum likelihood. 
This technique can be demonstrated with a two-indicator example in Figure I. In this example, both indicators are binary with grade I indicating immature and grade 2 indicating mature. As seen in Figure I for the first indicator, the probability of a mature score (grade 2) up to age 4 is zero. The probability of being scored as mature (grade 2) begins (becomes positive) at approximately five years of age, and increases with age so that by age 10 years the probability of a mature score is 0.5 . By age 14 , the probability of a mature score for this indicator is 1.0. For the second indicator, the probability of an immature score (grade 1 ) at age 4 is 1.0, at age 10, it is 0.8 , and by age 15 years the probability of an immature score is zero (i.e., no one at age 15 should be immature for this indicator). The joint likelihood for both these indicators is shown at the bottom of Figure I as the product of the two probability curves, where the likelihood of observing both a grade 2 for the first indicator and a grade I for the second indicator at less than age 7 or greater than age 13 years is minimal. The likelihood of the score $\{2,1\}$ is greatest at age 10.6 years. In this simple example, the skeletal age of a child with a score $\{2,1\}$ for just these two indicators would be 10.6 years (Roche et al., 1988).
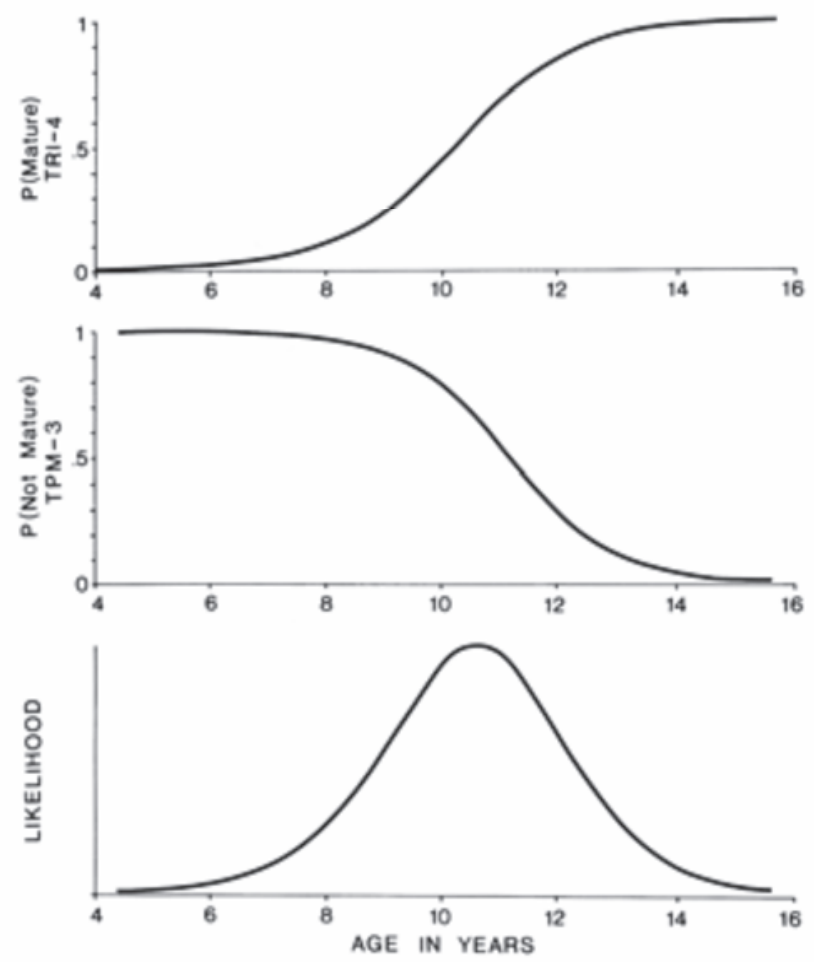

Figure I. Probability curves for two indicators and their joint likelihood in the FELS Method. 
Incorporating additional maturity indicators into the model follows the same pattern as described above with probability curves initially identified for each indicator followed by the construction of the joint likelihood model from those curves. When all indicators required at a chronological age are considered together, an estimate of skeletal age is determined. This skeletal age is based on multiple maturity indicators of various types from different bones, and the estimated skeletal age maximizes the information from the maturity indicators.

\section{COMPARISONS AMONG THE HAND-WRIST METHODS}

The Greulich-Pyle atlas method (Greulich \& Pyle, 1950) is generally used as a set of flash cards to locate subjectively the single atlas radiograph that most closely resembles the whole hand-wrist radiograph in question. This incorrect, overly simplified use of this assessment technique has resulted in limited reliability (Greulich \& Pyle, 1950; Tanner et al.,et al., 1975; Roche et al.,et al., 1988). In the early 1970's, it was recognized that this method did not reflect the skeletal age of normal healthy U.S. children accurately, and this was especially true for black children (Garn et al.,et al., 1967; Anderson, 1968). These findings have been reinforced repeatedly over the past several decades both in the U.S. for white, black, Hispanic- and Asian-American children (Loder et al., 1993; Ontell et al., 1996; Russell et al., 200 I; Mora et al., 200 I; Stanitski, 2006) and around the world (Shaikh et al., 1998; Bull et al., 1999; Koc et al., 200 I; Haiter-Neto et al., 2006). The Tanner-Whitehouse method (now in its third edition, TW3) (Tanner and Whitehouse, 1959, Tanner et al., 1962, 1997, 1975, 200I) is a more sophisticated assessment method than the GreulichPyle method that is based on scoring 20 bones in the hand-wrist to produce a skeletal maturity score (SMS) that measures skeletal maturity on an absolute (population invariant) scale. The SMS score can then be calibrated to any population of interest to produce a bone age. The TW3 bone age is calibrated to European and European-American populations. The population invariant nature of the SMS score, however, depends on the assumption that there are no population differences in the relative tempo of maturation among the bones of the hand-wrist. There is, in fact, some evidence that such differences exist, namely that there are secular trends of differing direction and magnitude in the timing of maturation of the bones of the hand-wrist (Duren et al., 20l0). Such secular differences within a single population imply that there are very likely to be betweenpopulation differences in the relative tempo of maturation of the bones of the hand-wrist. Thus, despite the calibration of TW3 to European-American children, it is not clear whether the underlying SMS scores are applicable to other than the European population used to derive them.

The FELS method provides accurate and reliable estimates of the skeletal ages of U.S. children (Roche et al., 1988). As part of the validity testing for this method, a sample of 500 radiographs from white and black children in the first National Health and Nutrition Examination Survey were assessed. The mean skeletal ages for these US children were similar to their mean chronological ages at the assessed ages of the radiographs. There 
was no systematic trend in the differences between the chronological and FELS skeletal ages for each sex. These findings indicated that the FELS method was appropriate for the U.S. pediatric population of white and black children at that time (Chumlea et al., 1989). The Greulich-Pyle and Tanner-Whitehouse methods lack accuracy, and have limited validity, and/or their levels of skeletal maturity do not reflect the skeletal age and maturity of normal U.S. children today. It is not possible to calculate confidence intervals for the estimated skeletal ages when using the Greulich-Pyle or Tanner-Whitehouse methods which are important in the proper interpretation of a skeletal age (Roche et al., 1988). These differences reflect both the underlying samples from which the methods were developed and the statistical methodology used to derive a skeletal age.

\section{SECULAR TREND IN SKELETAL MATURITY AS A RELEVANT HYPOTHESIS FOR ADDITIONAL RESEARCH}

Recent reports signal a world-wide secular trend in maturation (Karlberj, 2002) including skeletal maturity. Children today are more advanced in their skeletal maturity at least by age 10 years as compared to the children of just a few decades ago (Ranjitkar et al., 2006; Lin et al., 2006; Savaridas et al., 2007). Data from our own study sample, the Fels Longitudinal Study, indicate a trend for accelerated skeletal maturity in children born since 1960, compared to those born in the 30 years prior. We conducted a small pilot analysis to determine if a shift in the relative skeletal ages (chronological age less skeletal age) of Fels Longitudinal Study children has occurred. We randomly selected a small group of children ( $N=39$ to 69 depending on the age group) who had a hand-wrist radiograph at ages 8, II, 14 and 17 years before 1960 (one visit per child) and a random selection of unrelated Fels children ( $N=24$ to 46 depending on the age group) with corresponding age radiographs after 1990. Relative skeletal ages at the corresponding chronological ages are plotted in Figure 2.

The skeletal ages of the children with a radiograph before 1960 were used in the development of the FELS Method which explains the small values of their relative skeletal ages (in absolute value), which are similar to those reported in the details of the method (Roche et al., 1988). In comparison, contemporary Fels children have relative skeletal ages that are considerably larger (in absolute value), approaching a -0.8 year difference. These preliminary findings indicate that the FELS method is potentially underestimating the skeletal ages of these healthy children during the critical period of pubescence by half a year or more. Moreover, an investigation of the various types of maturity indicators contained in the FELS method has revealed differences in the tempo (and, in some cases, direction) of the secular trend in skeletal maturity, with indicators such as fusion of the epiphyses exhibiting the most extreme trends towards earlier maturation (Duren et al., $2010)$. 


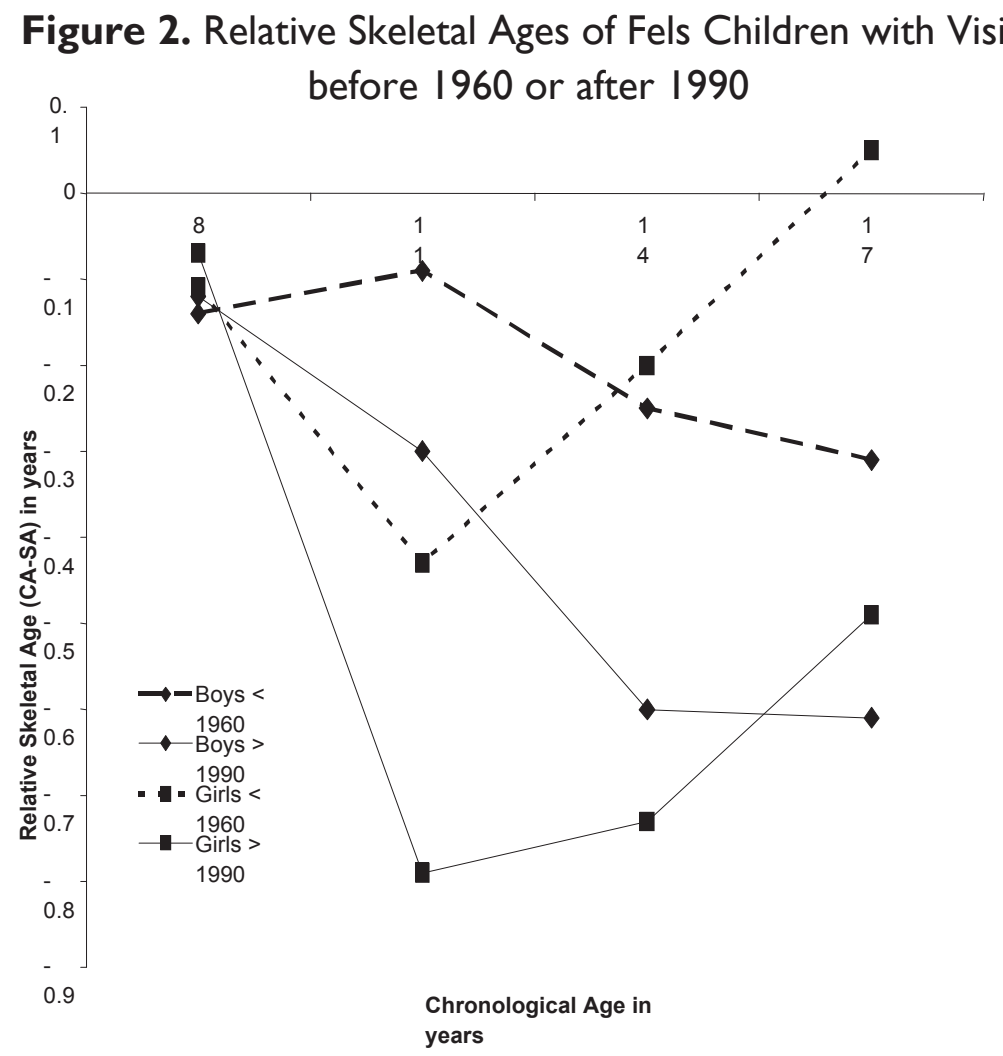

The accelerated maturation has implications for a variety of aspects of child growth, development, obesity and physical performance. This includes the potential age alterations in the timing of the magnitude of peak height velocity, bone mineral accrual, predicted adult stature, menarche and secondary sex characteristics and physical performance. Accelerated skeletal maturation as reflected in skeletal age can alter established uses of skeletal age in the interpretation of attained maturity at a chronological age affecting participation in youth sports (Malina et al,, 20l0). In order to assess reliably the associations, timings and onset among these maturational processes with skeletal age, it is imperative that skeletal age methods reflect the maturity status of contemporary children. To this end, the FELS Method is undergoing a revision that should be available shortly.

\section{ACKNOWLEDGMENT}

This work was supported by grant IRO I AR055927 from the National Institutes of Health, Bethesda, MD. 


\section{REFERENCES}

Anderson, E., 1968, Skeletal Maturation of Danish School Children in Relation to Height, Sexual Development, and Social Conditions. Acta Paediatrica Scandenavica, (Suppl |85): I.

Beunen, G.P., Malina, R.M., Renson, R., Simons, J., Ostyn, M. and Lefevre, J., 1992, Physical activity and growth, maturation and performance: a longitudinal study. Medicine Science Sports and Exercise, 24(5):576-585.

Bull, R.K., Edwards, P.D., Kemp, P.M., Fry, S. and Hughes, I.A., 1999, Bone age assessment: a large scale comparison of the Greulich and Pyle, and Tanner and Whitehouse (TW2) methods. Archive of Diseases of Childhood, 81 (2): I72- 173.

Chumlea, W.C., Roche, A.F. and Thissen, D., 1989, The Fels method of assessing the skeletal maturity of the handwrist. American Journal of Human Biology, I: I 75- 183.

Claessens, A.L., Lefevre, J., Beunen, G.P. and Malina, R.M., 2006, Maturity-associated variation in the body size and proportions of elite female gymnasts $14-17$ years of age. European Journal of Pediatrics, 165(3): I 86- 192.

Cole, A.J., Webb, L. and Cole, T.J., 1988, Bone age estimation: a comparison of methods. British Journal of Radiology, 61 (728):683-686.

Cox, L.A., 1997, The biology of bone maturation and ageing. Acta Paediatrica Supplement, 423:107-108.

Duren, D.L., Nahhas, R.W., Sherwood, R.J., Lee, M., Choh, A.C., Towne, B., Czerwinski, S.A., Siervogel, R.M. and Chumlea W.C., 2010 Secular trend for earlier skeletal maturation in US children. Journal of Bone and Mineral Research. 25(SupplI) www.asbmr.org/meetings/annualmeeting/abstracts | 0.aspx.

Garn, S.M., Rohmann, C.G., Blumenthal, T. and Silverman, F.N., 1967, Ossification communalities of the hand and other body parts: their implication to skeletal assessment. American Journal of Physical Anthropology, 27(1):75-82.

Greulich, W.W. and Pyle, S.I., 1950, Radiographic atlas of skeletal development of the hand and wrist. (Stanford, CA: Stanford University Press).

Haiter-Neto, F., Kurita, L.M., Menezes, A.V. and Casanova, M.S., 2006, Skeletal age assessment: a comparison of 3 methods. American Journal of Orthodontic and Dentofacial Orthopediatrics, I 30(4):435 e4I5-420.

Karlberg, J., 2002, Secular trends in pubertal development. Hormone Research, 57 Suppl 2:19-30.

Koc, A., Karaoglanoglu, M., Erdogan, M., Kosecik, M. and Cesur, Y., 200I, Assessment of bone ages: is the Greulich-Pyle method sufficient for Turkish boys? Pediatrics International, 43(6):662-665.

Lin, N.H., Ranjitkar, S., Macdonald, R., Hughes, T., Taylor, J.A. and Townsend, G.C., 2006, New growth references for assessment of stature and skeletal maturation in Australians. Australian Orthodontics J, 22(I): I- 10.

Loder, R.T., Estle, D.T., Morrison, K., Eggleston, D., Fish, D.N., Greenfield, M.L. and Guire, K.E., 1993, Applicability of the Greulich and Pyle skeletal age standards to black and white children of today. American Journal of Diseases of Childhood, I 47(I2):13291333. 
Malina, R.M., Katzmarzyk, P.T. and Beunen, G.P., 1999, Relation between birth weight at term and growth rate, skeletal age, and cortical bone at 6-II years. American Journal of Human Biology, I I (4):505-5 II.

Malina, R.M., Pena Reyes, M.E., Figueiredo, A.J., Coelho, E., Silva M.J., Horta, L., Miller, R., Chamorro, M., Serratosa L., Morate, F., 2010, Skeletal age in youth soccer players: implications for age verification. Clinical Journal of Sports Medicine, 20(6) 469-474.

Mora, S., Boechat, M.I., Pietka, E., Huang, H.K. and Gilsanz, V., 200I, Skeletal age determinations in children of European and African descent: applicability of the Greulich and Pyle standards. Pediatric Research, 50(5):624-628.

Ontell, F.K., Ivanovic, M., Ablin, D.S. and Barlow, T.W., 1996, Bone age in children of diverse ethnicity. American Journal of Roentgenology, I 67(6): I 395-1398.

Pyle, S.I. and Hoerr, N.L., 1969, A radiographic standard of reference for the growing knee. (Springfield, IL: Charles C Thomas,).

Ranjitkar, S., Lin, N.H., Macdonald, R., Taylor, J.A. and Townsend, G.C., 2006, Stature and skeletal maturation of two cohorts of Australian children and young adults over the past two decades. Australian Orthodontics J, 22( ( ):47-58.

Roche, A.F., 1980, The measurement of skeletal maturation. In: Human Physical Growth and Maturation: Methodologies and Factors. Johnston FE, Roche AF, Susanne C eds. New York: Plenum.

Roche, A.F., 1992, Growth, Maturation and Body Composition: The Fels Longitudinal Study 1929-1991. (Cambridge: Cambridge University Press).

Roche, A.F., Chumlea, W.C. and Thissen, D., 1988, Assessing the Skeletal Maturity of the Hand-Wrist: Fels Method. (Springfield: Charles C. Thomas).

Russell, D.L., Keil, M.F., Bonat, S.H., Uwaifo, G.I., Nicholson, J.C., McDuffie, J.R., Hill, S.C. and Yanovski, J.A., 200I, The relation between skeletal maturation and adiposity in African American and Caucasian children. Journal of Pediatrics, I 39 (6):844-848.

Sanders, J.O., Browne, R.H., McConnell, S.J., Margraf, S.A., Cooney, T.E. and Finegold, D.N., 2007, Maturity assessment and curve progression in girls with idiopathic scoliosis. American Journal of Bone and Joint Surgery, 89 (I):64-73.

Savaridas, S.L., Huntley, J.S., Porter, D.E., Williams, L. and Wilkinson, A.G., 2007, The rate of skeletal maturation in the Scottish population: a comparison across 25 years (19802005). Journal of Pediaticr Orthopedics, 27(8):952-954.

Shaikh, A.H., Rikhasor, R.M. and Qureshi, A.M., 1998, Determination of skeletal age in children aged 8- 18 years. Journal of the Pakistan Medical Association, 48(4): I 04- 106.

Stanitski, C.L., 2006, Skeletal maturity. Journal of Pediatric Orthopedics, 26(6):825-826.

Tanner, J.M. and Whitehouse, R.H., 1958 Standards for Skeletal Maturity. Part I. (Paris: International Children's Centre).

Tanner, J.M., Whitehouse, R.H.and Healy, M.J.R., 1962 A New System for Estimating Skeletal Maturity from the Hand Wrist, with Standards Derived from a Study of 2,600 Healthy British Children. Part II. (Paris: International Children's Centre).

Tanner, J., Oshman, D., Bahhage, F. and Healy, M., 1997, Tanner-Whitehouse bone age reference values for North American children. Journal of Pediatrics, I 3 I ( I Pt I):3440. 
Tanner, J., Whitehouse, R., Marshall, W., Healy, M. and Goldstein, H., 1975, Assessment of Skeletal Maturity and the Prediction of Adult Height (TW2 Method). (London: Academic Press).

Tanner, J.M., Healy, M.J.R., Goldstein, H. and Cameron, N., 200I Assessment of Skeletal Maturity and Prediction of Adult Height (TW3 Method). (London: W. B. Saunders). 